\title{
Entomopathogenic efficacy of the chitinolytic bacteria: Aeromonas hydrophila isolated from Siwa Oasis, Egypt
}

\author{
Shereen M. Korany ${ }^{1}$, Amany N. Mansour² $\mathbb{0}$, Hoda H. El-Hendawy ${ }^{1 *}$, Abdel Naser A. Kobisi ${ }^{2}$ and Hamdy H. Aly ${ }^{2}$
}

\begin{abstract}
Thirty-four bacterial isolates were isolated from soil samples collected from the North Western Coast and a water sample collected from brackish water at Siwa Oasis, Matrouh Governorate, Egypt. Only six isolates showed chitinase activity when screened on colloidal chitin agar medium. The highest chitinolytic activity was achieved by a bacterial isolate labeled as A.S. This isolate was identified as Aeromonas hydrophila based on analysis of 16 S rRNA gene sequence and morphological, physiological, and biochemical characteristics. Optimization of the cultural conditions for maximum chitinase production by $A$. hydrophila revealed that the highest level of chitinase was recorded when the bacterium was grown in malt nitrogen-based medium containing $1 \%$ colloidal chitin at $\mathrm{pH} 7 \mathrm{for} 48 \mathrm{~h}$ incubation at $30^{\circ} \mathrm{C}$. Crude chitinase from isolate $A$. hydrophila was evaluated against first instar larvae of the greater wax moth; Galleria mellonella L. (Lepidoptera: Pyralidae) at different concentrations of 0, 185, 205, 235, 265, $295 \mathrm{U} / \mathrm{mg}$ protein. It increased larval and pupal mortality rates in a concentration-dependent manner. The tested crude chitinase significantly induced a decrease in adults' emergence rate and their fecundity.
\end{abstract}

Keywords: Entomopathogens, Bacteria, Chitinase, Aeromonas hydrophila, Galleria mellonella

\section{Background}

Chitin, a $\quad \beta-1, \quad$ 4-linked polymer of $\mathrm{N}$-acetyl-D-glucosamine, is one of the most abundant polysaccharides in nature, next to cellulose (Elieh-Ali-Komi and Hamblin, 2016). It is widely distributed in nature as a structural component of crustaceans, fungi, and insects (Flach et al. 1992). In insects, chitin is present in the cuticle, gut lining, salivary glands, tracheal tubes, eggshells, and muscles (Kramer and Koga, 1986). Therefore, it is a great target for controlling insect pests.

Chitinases (E.C. 3.2.1.14) are a group of enzymes that play a pivotal role in recycling chitin in the nature. They are known to perform many biological functions and produced by organisms such as bacteria, fungi, actinomycetes, insects and high plants (Jabeen et al. 2018). Microorganisms produce chitinases in order to utilize chitin as an energy source whereas fungi and insect produce chitinases as they are involved in morphogenesis (Kitamura and Kamei, 2003).

\footnotetext{
* Correspondence: el-hendawi@hotmail.com

${ }^{1}$ Botany and Microbiology Department, Faculty of Science, Helwan University, Cairo, Egypt

Full list of author information is available at the end of the article
}

Microbes producing chitinases have received much attention regarding their potential development as biopesticides. However, studies have mainly focused on the use of chitinase producing entomopathogenic fungi (EPF) and not much work has been carried out on the efficacy of chitinolytic bacteria in pest control (Aggarwal et al., 2015). Although these fungi are widely used to control insect pests, they have not been commercially successful due to their slow killing rates (Stock, 2009). EPF infect insects by penetrating the cuticle, while the bacterial entomopathogens are obtained via host feeding and infection of the gut. These bacteria enzymatically cleave the chitin present in the peritrophic membrane of the insect gut causing perforations, leading to disease and subsequent death of the infected larvae (Chandrasekaran et al. 2012). Thus, bacteria represent a very attractive alternative to the EPF because of their relatively speed of killing (Khan et al. 2012).

The aim of this study was to isolate the most prominent chitinolytic bacteria from different soil and water samples collected from Matrouh Governorate, Egypt and to determine the most suitable growth conditions for 
Table 1 Qualitative chitinolytic activity of the isolated bacteria on colloidal chitin media

\begin{tabular}{llll}
\hline Isolates & $\begin{array}{l}\text { Colony diameter } \\
(\mathrm{mm})\end{array}$ & $\begin{array}{l}\text { Clear zone diameter } \\
(\mathrm{mm})\end{array}$ & Chitinolytic index \\
\hline IC15.a & 14.2 & 20.5 & 0.4 \\
IC15.b & 15.0 & 22.0 & 0.4 \\
IC21 & 15.0 & 20.0 & 0.3 \\
G2 & 12.5 & 20.0 & 0.6 \\
'G & 12.5 & 17.5 & 0.4 \\
A.S & 10.0 & 22.5 & 1.2 \\
\hline
\end{tabular}

maximum chitinase production. Larvicidal effect of the crude chitinase was also investigated.

\section{Materials and methods}

\section{Isolation of chitinolytic bacteria}

Soil and water samples were collected from different localities of the North Western Coast, Siwa Oasis, Matrouh Governorate, Egypt during April 2016. The chitinolytic bacteria were isolated from the collected samples by plating them on agar medium amended with $1.5 \%$ colloidal chitin. The medium consisted of $\left(\mathrm{g} \mathrm{l}^{-1}\right): \mathrm{Na}_{2} \mathrm{HPO}_{4}, 6$; $\mathrm{KH}_{2} \mathrm{PO}_{4}, 3 ; \mathrm{NH}_{4} \mathrm{Cl}, 1 ; \mathrm{NaCl}, 0.5$; yeast extract, 0.05 ; agar, 15; and colloidal chitin, $15 \mathrm{~g}$ (Kuddus and Ahmad, 2013). The formation of clear zones around the bacterial colony after incubation for $48 \mathrm{~h}$ at $30^{\circ} \mathrm{C}$ indicated their chitinolytic activity and was purified on collodial chitin agar medium, then maintained on nutrient agar slants at $4{ }^{\circ} \mathrm{C}$ and subcultured monthly for further studies.

\section{Preparation of colloidal chitin}

Colloidal chitin was prepared from purified chitin (Qualikems) according to the method of Roberts and Selitrennikoff (1988) with few modifications as $5 \mathrm{~g}$ of chitin powder was added slowly to $90 \mathrm{ml}$ of concentrated hydrochloric acid under vigorous stirring for $2 \mathrm{~h}$. The mixture was added to $500 \mathrm{ml}$ of ice-cold $95 \%$ ethanol with rapid stirring and kept overnight at $25^{\circ} \mathrm{C}$ and then stored at $20^{\circ} \mathrm{C}$ until use. When needed, the colloidal chitin was collected by centrifugation at $6000 \mathrm{rpm}$ for $10 \mathrm{~min}$ at $4{ }^{\circ} \mathrm{C}$ and the $\mathrm{pH}$ value was adjusted by addition of $1 \mathrm{~N} \mathrm{NaOH}$ or $\mathrm{HCl}$ until the $\mathrm{pH}$ value reached 7. The colloidal chitin was then kept at $4{ }^{\circ} \mathrm{C}$ used for future application.

\section{Confirmation of chitinase production by the isolated bacteria}

Confirmation of chitinase production on chitin agar plates by the purified bacterial colonies was carried out by streaking each bacterial isolate on these plates and incubation at $30^{\circ} \mathrm{C}$ for $48 \mathrm{~h}$. Two replicates were prepared for each isolate, measurement of extracellular enzyme activity on the plate was carried out as described by Bradner et al. (1999), the diameter of the developed colony and the clear zone

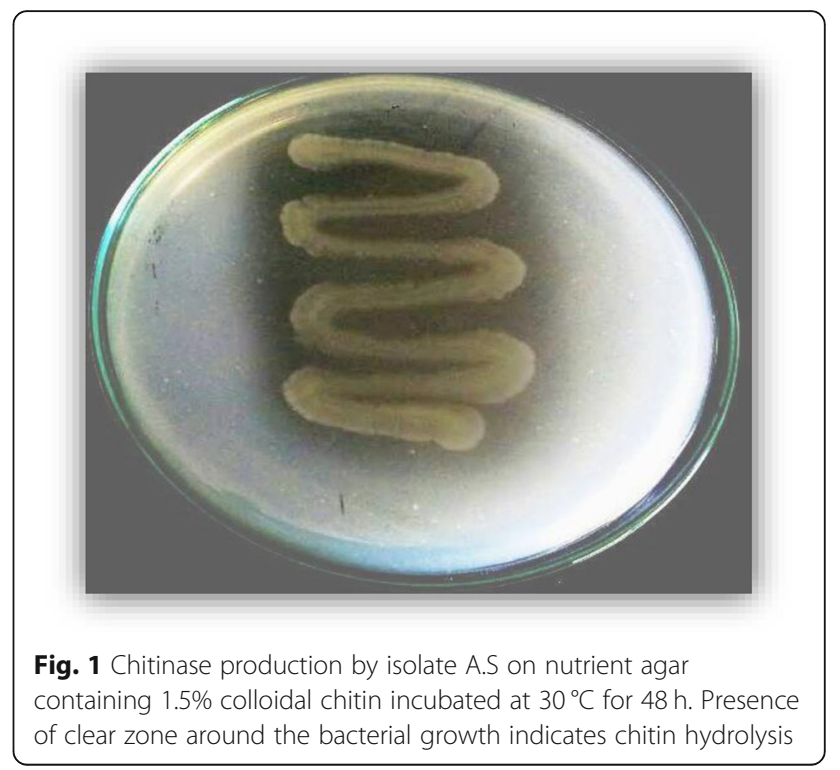

was measured in two dimensions at $90^{\circ}$ to each other, and the sum of the values was averaged. Chitinolytic index was calculated according to the following equation:

$$
\text { Chitinolytic index }=\frac{\text { Clear zone diameter-Colony diameter }}{\text { Colony diameter }}
$$

Bacterial colony with chitinolytic index value of 1 or greater was classified as significant enzyme activity (Duncan et al. 2006).

\section{Characterizations of bacterial isolate Identification of chitinolytic bacteria by 165 rRNA gene sequence analysis}

DNA was extracted, using PrepMan ${ }^{\text {th }}$ Ultra Sample Preparation Reagent, Applera (Thermo Fisher Scientific, Cat \# 4318930) according to instructions of the manufacturer. The extract was used as a template to amplify a 527-bp fragment of the 16S rRNA gene, using MicroSEQ ${ }^{\text {tw }} 50016 \mathrm{~S}$ rDNA PCR Kit (Thermo Fisher Scientific, Cat \# 4348228) according to the instructions of the manufacturer. The obtained nucleotide sequences were Mega blasted to the total nucleotide collection of NCBI, using Basic Local Alignment Search Tool for nucleotide blast (https://blast.ncbi.nlm.nih.gov/Blast.cgi). Phylogenetic tree is constructed using UPGMA tree build method in Geneious 8.1.9 software.

\section{Transmission electron microscopic examination}

TEM studies of isolate A.S grown in nutrient broth (NB) medium under static condition for $24 \mathrm{~h}$ were carried out to observe flagella. The bacterial suspension was mounted on a copper grid coated with carbon, stained by uranyl sulfate and then investigated by the transmission electron microscope (Philips 208S) in the Electron 


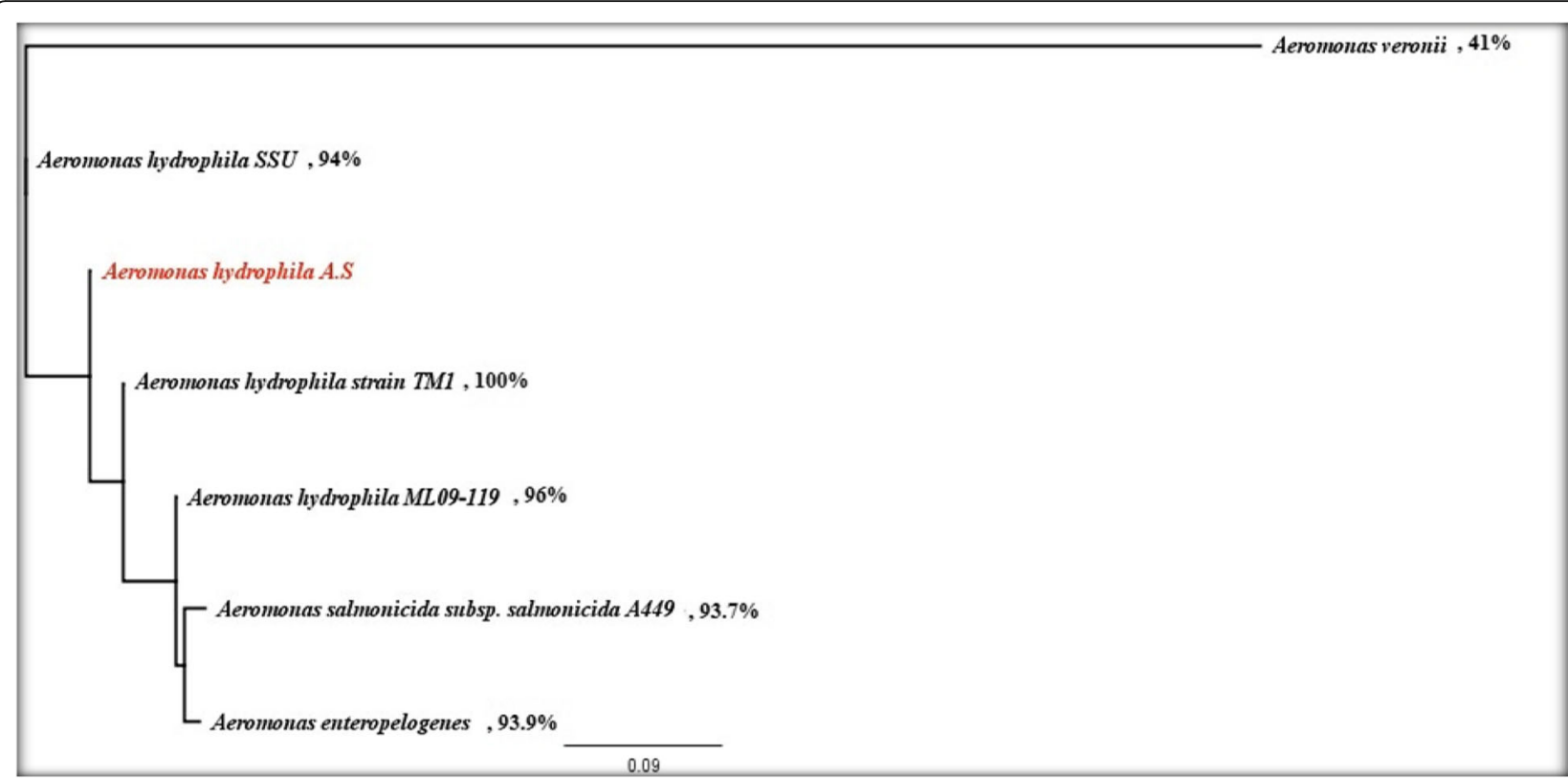

Fig. 2 Rooted phylogenetic tree of 16S rRNA gene of isolate A.S

Microscopy Research Department at Theodor Bilharz Research Institute, Cairo, Egypt.

\section{Morphological, physiological, and biochemical characterizations of chitinolytic isolate}

Morphological, physiological, and biochemical characterizations of this isolate were performed according to Martin-Carnahan and Joseph (2005).

\section{Chitinase production in liquid medium}

Growing of isolate A.S to monitor the production of chitinase was carried out as described by Zarei et al. (2011) in chitin mineral salt medium containing $\left(\mathrm{g} \mathrm{l}^{-1}\right)$ colloidal chitin, $5 ; \mathrm{MgSO}_{4} .7 \mathrm{H}_{2} \mathrm{O}, 0.5 ; \mathrm{KH}_{2} \mathrm{PO}_{4}, 0.3 ; \mathrm{K}_{2}$ $\mathrm{HPO}_{4}, 0.7$; yeast extract, 0.3 ; peptone, $0.3 ; \mathrm{NaCl}, 1.0$; $\left(\mathrm{NH}_{4}\right)_{2} \mathrm{SO}_{4}, 1.0 ; \mathrm{MnSO}_{4} .2 \mathrm{H}_{2} \mathrm{O}, 1.6 ; \mathrm{ZnSO}_{4} .7 \mathrm{H}_{2} \mathrm{O}, 1.4$; $\mathrm{FeSO}_{4} \cdot 6 \mathrm{H}_{2} \mathrm{O}, 5$; and $\mathrm{CaCl}_{2}, 2$ g. Each flask containing 50 $\mathrm{ml}$ of the medium was inoculated by $1.0 \mathrm{ml}$ of bacterial suspension, containing approximately $\left(7 \times 10^{8} \mathrm{cfu} \mathrm{ml}^{-1}\right)$ prepared from an overnight shake culture grown in nutrient broth. Inoculated flasks were incubated in an orbital shaker at $150 \mathrm{rpm}$ and $30^{\circ} \mathrm{C} \pm 2$ for $48 \mathrm{~h}$. The culture supernatant was obtained by centrifugation at $10,000 \mathrm{rpm}$ and $6^{\circ} \mathrm{C}$ for $20 \mathrm{~min}$ and then was filter sterilized by passing through $0.45 \mu \mathrm{m}$ Millipore nitrocellulose membrane filter type $\mathrm{WCN}$ and stored at $-20^{\circ} \mathrm{C}$.

\section{Chitinase assay}

Enzyme assay was carried out as described by Ulhoa and Peberdy (1991) using a culture supernatant as crude enzyme and colloidal chitin as substrate. Chitinolytic activity was measured by incubating $3.0 \mathrm{ml}$ of $0.5 \%$ colloidal chitin suspended in $50 \mathrm{mM}$ sodium acetate buffer $\mathrm{pH}$ 5.20 mixed with $3.0 \mathrm{ml}$ enzyme solution (culture supernatant). The mixture was incubated at $40{ }^{\circ} \mathrm{C}$ with shaking at $150 \mathrm{rpm}$ for $24 \mathrm{~h}$ and then centrifuged at $4000 \mathrm{rpm}$ for $5 \mathrm{~min}$ at room temperature. The amount of reducing sugar released in the supernatant was determined according to Miller (1959). One unit of enzyme activity was expressed as the amount of enzyme releasing $1 \mu \mathrm{mol}$ $\mathrm{N}$-acetyl glucosamine (NAGA)/min from colloidal chitin, under assay conditions (Ghanem et al. 2011).

$$
\text { Specific activity }(\text { S.A })=\frac{\text { Chitinase activity }(\mathrm{U} / \mathrm{min})}{\text { Extracelluar protein }(\mathrm{mg} / \mathrm{ml})}
$$

\section{Optimization of culture conditions for chitinase production}

Protein concentration was estimated by the method of Bradford (1976). For optimum incubation time, the bacterial isolate was grown in the previously mentioned medium and conditions for 4 days, and chitinase production was determined every $24 \mathrm{~h}$. The effect of temperature on enzyme production was determined by incubating inoculated medium at different temperatures $(20,25,30,35$, and $40{ }^{\circ} \mathrm{C}$ ). Chitinase activity and protein concentration were estimated as described before. The effect of the initial $\mathrm{pH}$ value on chitinase production by isolate A.S was investigated by varying the initial $\mathrm{pH}$ of the culture medium along the value of 3 to 11 and at an optimized temperature and incubation period. Chitinase activity and protein concentration were estimated as described before. To select the best nitrogen source, the chitin media was supplemented with different inorganic nitrogen source as 
Table 2 Physiological and biochemical characteristics of isolate A.S compared to those reported for Aeromonas hydrophila by Abbott et al. (2003), Martin-Carnahan and Joseph (2005), and Erdem et al. (2011)

\begin{tabular}{|c|c|c|c|c|}
\hline Characteristics & $\begin{array}{l}\text { Isolate } \\
\text { A.S }\end{array}$ & Abbott et al. (2003) & (Martin-Carnahan and Joseph. (2005) & Erdem et al. (2011) \\
\hline Gram reaction & - & - & - & - \\
\hline Spore & - & - & - & - \\
\hline Indole production & + & + & + & + \\
\hline Methyl red (M.R) & + & $\mathrm{nt}$ & $\mathrm{nt}$ & + \\
\hline Voges-Proskauer (V-P) & + & + & + & + \\
\hline Citrate (Simmons') & + & + & $d$ & nt \\
\hline Nitrate reduction media & + & nt & + & + \\
\hline Urea hydrolysis & - & - & - & - \\
\hline Triple sugar iron (TSI) & - & $\mathrm{nt}$ & $\mathrm{nt}$ & nt \\
\hline Growth in $0 \% \mathrm{NaCl}$ & + & + & + & + \\
\hline Growth in $3 \% \mathrm{NaCl}$ & + & + & + & $\mathrm{nt}$ \\
\hline Growth in KCN & - & + & + & + \\
\hline Motility test & + & + & + & + \\
\hline Oxidase activity & + & + & + & + \\
\hline Catalase test & + & + & + & + \\
\hline Arginine dihydrolase & + & + & + & + \\
\hline Ornithine decarboxylase & - & - & - & - \\
\hline Lysine decarboxylase & + & + & + & + \\
\hline Hemolysis & + & + & + & + \\
\hline \multicolumn{5}{|l|}{ Hydrolysis of: } \\
\hline Starch & + & nt & nt & + \\
\hline Cellulose & - & $\mathrm{nt}$ & $\mathrm{nt}$ & $\mathrm{nt}$ \\
\hline Lipid & + & + & + & nt \\
\hline Gelatin & + & + & + & + \\
\hline
\end{tabular}

Symbols: - ; $0-10 \%$ positive;,$+ 90-100 \%$ positive; nt, not tested

ammonium chloride and ammonium sulfate and organic nitrogen source such as yeast extract, peptone, malt extract, and gelatin. Nitrogen sources were used at a concentration of $0.3 \mathrm{gl}^{-1}$. The supplemented media were inoculated by $1.0 \mathrm{ml}$ inoculums and fermented at optimized conditions. Media without any carbon and nitrogen source were used as control. Chitinase activity and protein concentration were estimated as described before. Effect of carbon sources like glucose, mannitol, starch, lactose, and fructose on chitinase production was investigated. The carbon sources were used at a concentration of $5 \mathrm{gl}^{-1}$. The supplemented media were inoculated by $1.0 \mathrm{ml}$ of an overnight culture containing approximately $7 \times 10^{8} \mathrm{cfu} \mathrm{m}^{-1}$ inoculums and fermented at an optimized condition. Simultaneously media without any carbon and nitrogen source compared with media containing colloidal chitin as control. Chitinase activity and protein concentration were estimated as described before. Different concentrations of chitin such as $0.1,0.3,0.6,0.8,1$, and $1.2 \%$ were used in the growth medium to determine best chitin concentration. Chitinase activity and protein concentration were estimated as described before.

\section{Larvicidal effect of crude chitinase against Galleria mellonella}

Bioassay was performed on the first larval instar of $G$. mellonella using $2 \mathrm{~g}$ of artificial diet (Bhatnagar and Bareth, 2004) mixed with $0.1 \mathrm{ml}$ of 295, 265, 235, 205, $185 \mathrm{U} / \mathrm{mg}$ protein crude chitinase. Thirty larvae per concentration were used for all the treatments as well as control. All larvae were kept at a constant temperature $27 \pm 2{ }^{\circ} \mathrm{C}$. Daily inspections were carried out until adult emergence. Larval mortality, pupation, pupal mortality rate, and adult malformation were recorded. In addition, fecundity, deficient fecundity percentage, and oviposition deterrent index were calculated for emerged adults according to the following equations:

$$
\begin{gathered}
\text { A.Fecundity }=\text { Number of egg laid per female } \\
\text { B.Deficient fecundity } \%=C-T \times \frac{100}{T} \\
\text { C.Oviposition deterrent index }=\frac{C-T}{C+T} \times 100
\end{gathered}
$$

Where $C$ and $T$ are the mean numbers of eggs laid in control and treated artificial diet, respectively (Huang et al. 
Table 3 Acid production from saccharides by isolate A.S compared to those reported for Aeromonas hydrophila by Abbott et al. (2003), Martin-Carnahan and Joseph. (2005) and Erdem et al. 2011)

\begin{tabular}{|c|c|c|c|c|}
\hline Characteristics & $\begin{array}{l}\text { Isolate } \\
\text { A.S }\end{array}$ & Abbott et al. (2003) & Martin-Carnahan and Joseph. (2005) & Erdem et al. (2011) \\
\hline D-glucose (gas) & + & + & + & + \\
\hline Lactose & + & + & $d$ & $d$ \\
\hline Sucrose & + & + & + & $\mathrm{nt}$ \\
\hline Maltose & + & + & + & + \\
\hline L-arabinose & + & + & $d$ & + \\
\hline L-rhamnose & - & + & $d$ & $d$ \\
\hline D-xylose & - & nt & - & - \\
\hline Cellobiose & - & - & - & nt \\
\hline D-trehalose & + & nt & + & + \\
\hline D-raffinose & - & - & - & - \\
\hline Adonitol & - & - & - & nt \\
\hline Dulcitol & - & nt & - & - \\
\hline Glycerol & - & + & + & + \\
\hline Inositol & - & + & - & - \\
\hline D-mannitol & + & + & + & + \\
\hline Salicin & + & + & $d$ & $d$ \\
\hline Melibiose & - & - & - & - \\
\hline D-arabitol (gas) & + & nt & - & - \\
\hline Mannose & + & + & + & + \\
\hline \multicolumn{5}{|c|}{ Symbols:,$- 0-10 \%$ positive;,$+ 90-100 \%$ positive; $d, 26-75 \%$ positive; $n t$, not tested. } \\
\hline
\end{tabular}

1994). Mortality rates were corrected according to Abbott, 1925 and were subjected to probit analysis (Finney, 1971) to calculate the mean lethal concentration $\left(\mathrm{LC}_{50}\right)$.

\section{Statistical analysis}

Data were analyzed through one-way ANOVA, using SPSS Program. All data are graphically presented as the mean \pm SE, using Microsoft Excel 2010 .

\section{Results and discussion}

\section{Isolation of chitinolytic bacteria}

Thirty-four bacterial isolates were isolated from the soil samples collected from different localities at North Western Coast, as well as one isolate from brackish water at Siwa Oasis, Matrouh Governorate, Egypt. These 35 bacterial isolates were screened for chitinase production on selective medium containing $1.5 \%$ colloidal chitin agar. Only six bacterial isolates showed chitinase activity evidenced by clear zone formation around the bacterial growth due to hydrolysis of colloidal chitin. These isolates were IC15.a, IC15.b, IC21, G2, /G, and A.S. Isolate A.S was found to be the most potent isolate in chitinase production as it showed the highest chitinolytic index (Table 1 and Fig. 1). Potential chitinase producing bacterial isolates have been reported for isolates obtained from different sources such as pepper, onion, cabbage and orange peel (EL-Hendway et al. 2008), wastewater of shrimp culture ponds in Southern Iran (Zarei et al., 2010), soil samples collected from different habitats of Lucknow, India (Kuddus and Ahmad 2013), the rhizosphere of Medicago sativa (Abada et al. 2014), and fish market soil samples (Tariq, 2015).

\section{Characterization of the chitinolytic bacterial isolate A.S Analysis of $16 \mathrm{~S}$ rRNA gene sequence}

The isolate A.S was identified by analysis $16 \mathrm{~S}$ rRNA gene sequence. The homology of partial 16S rRNA gene sequence of the tested isolate was analyzed, using the BLAST algorithm in GenBank. Only the highest scored BLAST result was considered for phylotype identification. BLAST showed that isolate A.S had a maximum homology (100\%) with Aeromonas hydrophila TML (Fig. 2).

\section{Morphological, physiological, and biochemical characteristics of isolate A.S}

Based on the results obtained from 16S rRNA gene sequence analysis, morphological, physiological, and biochemical characteristics of the isolate A.S were similar to those reported for A. hydrophila in the literature (Abbott et al. 2003; Martin-Carnahan and Joseph, 2005 and Erdem et al. 2011). This isolate deviated from the standard description in growth in $\mathrm{KCN}$ and acid production from glycerol. Minor differences were detected, especially in the acid production from either inositol or 


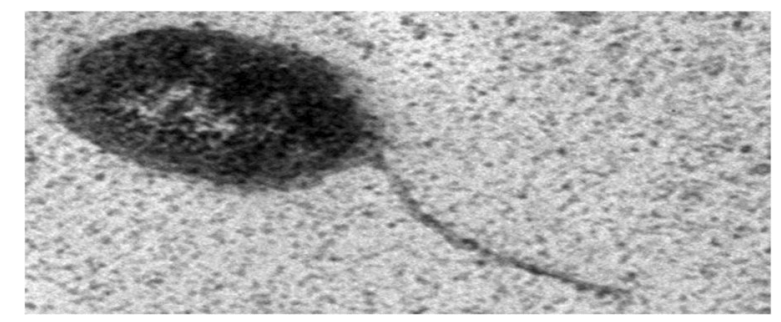

Fig. 3 Electron microphotograph of Aeromonas hydrophila isolate A.S with one polar flagellum (static growth on NB, 24 h; X 44000)

arabitol, but these do not contradict that the isolate A.S was A. hydrophila (Tables 2 and 3). As illustrated in Fig. 3, the electron microscopic examination revealed that this isolate had a single polar flagellum, which was reported for A. hydrophila (Merino and Tomás 2016).

\section{Optimization of chitinase production}

In an attempt to optimize the enzyme production by $A$. hydrophila isolate A.S, the effects of several parameters such as incubation time, temperature, $\mathrm{pH}$ values, nitrogen source, carbon source, and colloidal chitin concentration were investigated.

\section{Effect of incubation period}

The obtained results indicated that maximum chitinase activity was achieved after $48 \mathrm{~h}$ incubation period, and it was $85.28 \pm 4 \mathrm{U} / \mathrm{mg}$ protein. The enzyme production decreased at $96 \mathrm{~h}$ incubation period to $23.49 \pm 0.98 \mathrm{U} / \mathrm{mg}$ protein with insignificant difference in enzyme production during the incubation for $72 \mathrm{~h}$ relative to the amount of the enzyme produced in case of incubation for $96 \mathrm{~h}$ (Fig. 4a). The reduction in enzyme production could be attributed to lack of nutrients or production of toxic chemicals in the medium resulting in inactivation of the secretary machinery of the enzyme (Binod et al. $2007 \mathrm{a}, \mathrm{b})$ or could be due to degradation of the produced enzyme by the action of proteases produced by the bacterium (Karthik et al. 2014). These results agree with that reported by Kuddus and Ahmad (2013) who obtained a maximum chitinase activity from $A$. hydrophila and Aeromonas punctata after $48 \mathrm{~h}$.

Effect of temperature on chitinase production by isolate A.S The optimum temperature of the enzyme production by the isolate A.S was $30{ }^{\circ} \mathrm{C}$ and the specific activity was $80.78 \pm 1.29 \mathrm{U} / \mathrm{mg}$ protein (Fig. $4 \mathrm{~b}$ ). This result agrees with that reported by Thakkar et al. (2016) who found that maximum chitinase activity from Bacillus spp. was achieved at $30^{\circ} \mathrm{C}$, while the lowest one, $22.89 \pm 0.41 \mathrm{U} /$ mg protein, was found to be at $40^{\circ} \mathrm{C}$.

\section{Effect of different $\mathrm{pH}$ values on chitinase production by} isolate A.S

The obtained results revealed that chitinase production was greatly affected by the initial $\mathrm{pH}$ value of the culture medium. Among different $\mathrm{pH}$ values tested along the range of 3 to 11, pH7 was favored for chitinase production with a maximum enzyme activity of $56.13 \pm 0.85 \mathrm{U} /$ $\mathrm{mg}$ protein. These results agree with that reported by Karunya (2011) who found that optimum pH value for chitinase production by Bacillus subtilis was recorded over the range of $7-8$, where the enzyme activity decreased at lower $\mathrm{pH}$ values (Fig. 4c).

\section{Effect of different nitrogen sources on chitinase production by isolate A.S}

Differences in the level of chitinase production were obtained, when growing A. hydrophila isolate A.S in a medium supplemented with different organic nitrogen sources such as peptone, yeast extract, malt extract and gelatin, and two more inorganic nitrogen sources such as ammonium sulfate and ammonium chloride. They were added to mineral salt medium containing $0.5 \% \mathrm{col}-$ loidal chitin as described above. After inoculation with $7 \times 10^{8} \mathrm{cfu} \mathrm{ml}^{-1}$ and incubation at $30^{\circ} \mathrm{C}$ for $48 \mathrm{~h}$, among the nitrogen sources investigated, malt extract was the best nitrogen source for chitinase production (Fig. 4d). This could be attributed to the presence of nitrogenous compounds, growth factors, and oligomers of GlcNAc in this medium and its addition had a stimulatory effect on cell growth (Nawani and Kapadnis, 2005). Zarei et al. (2010) reported that malt extract was the optimum nitrogen source for chitinase production by $S$. marcescens B4A.

\section{Effect of different carbon sources on chitinase production by isolate A.S}

Five different carbon sources, namely, glucose, mannitol, starch, lactose, and fructose were supplemented at the concentration of $0.5 \%$ to the medium and then the enzyme activity was tested after inoculation and incubation as previously described. The activity was compared with that obtained from control medium contained colloidal chitin as a sole source for carbon. The obtained results indicated that colloidal chitin was the best carbon source for the production of chitinase by this bacterial isolate. Other workers also found that chitin or colloidal chitin was indispensable for chitinase production and was recommended, using of colloidal chitin as a sole source of carbon for highest chitinase production (Priya et al. 2011). The enzyme production was decreased in the presence of glucose, lactose, fructose, starch, and mannitol in comparison with the production in the presence of colloidal chitin, evidenced by the highest level of enzyme 


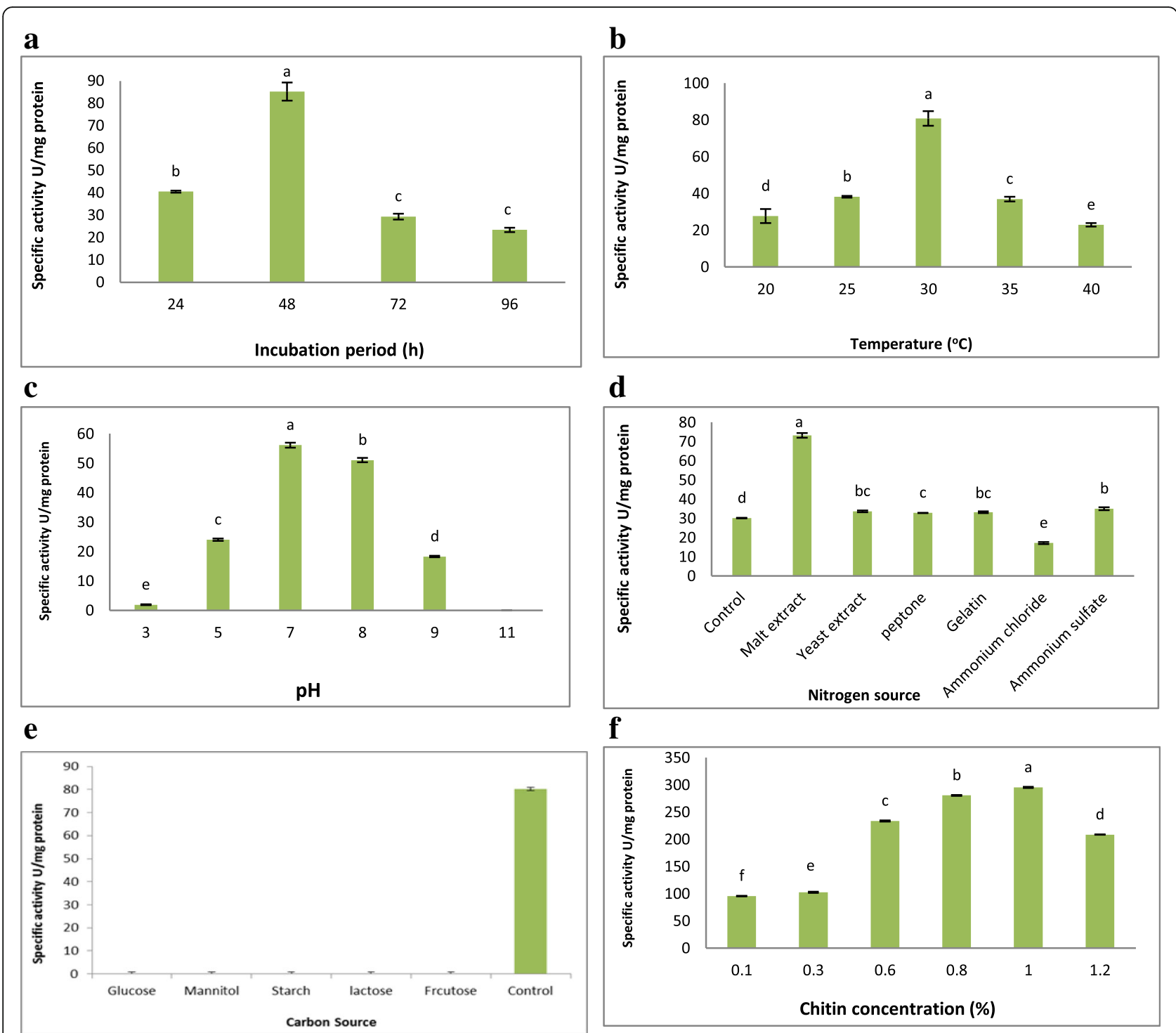

Fig. 4 Effect of different conditions on chitinase production by Aeromonas hydrophila isolate A.S. Effect of incubation period (a), temperature (b), $\mathrm{pH}$ value $(\mathbf{c})$, different nitrogen sources (d), different carbon sources (e), and different concentrations of colloidal chitin (f) on production of chitinase by Aeromonas hydrophila

activity, which was found to be $80.23 \pm 0.8 \mathrm{U} / \mathrm{mg}$ protein (Fig. 4e).

\section{Effect of chitin concentration on chitinase production by isolate A.S}

Different colloidal chitin concentrations $(0.1,0.3,0.6$, $0.8,1$, and $1.2 \%$ ) were used to determine the optimum concentration for maximum chitinase production by the bacterial isolate A.S. The results indicated that it was achieved in the presence of $1 \%$ chitin as the highest level of enzyme activity $(295.57 \pm 1.03 \mathrm{U} / \mathrm{mg}$ protein) was obtained (Fig. 4f). This result is in agreement with that reported by EL-Hendway et al. (2008) and Thakkar et al. (2016).

\section{Effect of crude chitinase on greater wax moth $G$.}

\section{mellonella}

\section{Lethal effect on mortality percentage of $G$. mellonella}

Some biological aspects of G. mellonella after treatment of the first larval instar were studied. Larval mortality (percentage) of G. mellonella increased as the crude chitinase concentration increased (Table 4). The highest concentration ( $295 \mathrm{U} / \mathrm{mg}$ protein) induced $90 \%$ mortality of larvae that gradually decreased to $60 \%$ at $185 \mathrm{U} / \mathrm{mg}$ protein compared to $26.66 \%$ larval mortality at control. The recorded larval mortality is probably due to the hydrolytic chitinase enzyme produced by $A$. hydrophila. This enzyme may damage the peritrophic membrane that lines the midgut and protects the epithelial cells, 
Table 4 Effect of crude chitinase on mortality percentage of different

\begin{tabular}{|c|c|c|c|c|c|}
\hline $\begin{array}{l}\text { Conc. (U/mg } \\
\text { protein) }\end{array}$ & $\begin{array}{l}\text { Larval } \\
\text { mortality (\%) }\end{array}$ & $\begin{array}{l}\text { Pupal } \\
\text { mortality (\%) }\end{array}$ & $\begin{array}{l}\text { Individuals failed to develop to adults } \\
\text { (observed) (\%) }\end{array}$ & $\begin{array}{l}\text { Individuals failed to develop to adults } \\
\text { (corrected) (\%) }\end{array}$ & $\begin{array}{l}\mathrm{LC}_{50} \\
\text { (U/mg } \\
\text { protein) }\end{array}$ \\
\hline 0 & 26.66 & 0.00 & 26.66 & 0.00 & 135 \\
\hline 185 & 60.00 & 13.33 & 73.33 & 63.63 & \\
\hline 205 & 70.00 & 13.33 & 83.33 & 77.27 & \\
\hline 235 & 83.33 & 3.33 & 86.33 & 81.81 & \\
\hline 265 & 89.65 & 0.00 & 89.65 & 85.89 & \\
\hline 295 & 90.00 & 0.00 & 90.00 & 86.36 & \\
\hline
\end{tabular}

which are very important in insect feeding (Bonnay et al. 2013). Once the peritrophic membrane degraded by chitinase, insect feeding may stop and consequently, the insect undergoes a lot of suffering or death (Bahar et al. 2012). Moreover, epithelium becomes indefensible and therefore, microbial pathogens may invade the insect hemocoel, where it multiplies and leads to death due to septicemia (Aggarwal et al. 2017). The present outcomes agree with the results of Binod et al. (2007a, b) who reported that chitinase can induce at least 50\% larval mortality of Helicoverpa armigera Hubner (Lepidoptera: Noctuidae) till pupal stage.

The artificial diet supplemented with crude chitinase from $A$. hydrophila (Table 4 ) induced $13.33 \%$ pupal morality at 185 and $205 \mathrm{U} / \mathrm{mg}$ protein and 3.3\% pupal morality at $235 \mathrm{U} / \mathrm{mg}$ protein. On the other hand, crude chitinase did not affect pupal mortality at the highest concentrations (265 and $295 \mathrm{U} / \mathrm{mg}$ protein). It is worth to note that pupae were observed to recover from treatments with crude chitinase at the highest concentrations, while in the lower concentration, higher percent of pupal mortality was induced. The possible explanation is due to high larval mortality at high concentrations that resulted in few numbers of surviving larvae. These larvae were the most resistant and at the onset of pupation, as they showed a higher percent of recovery compared to low concentrations. These results are in harmony with Kaur et al. (2014) who found that at the highest concentrations pupae formed from treated larvae remained in pupal stage till the termination of the experiment.

Larval mortality during the present study clearly affected the total mortality rates that followed the same trend (Table 4). This is due to the presence of a positive relationship between larval and total mortality percentages that increased with the increase in crude chitinase concentrations. The present outcomes agree with the results of Bakr et al. (2010) who mentioned that there was a positive relationship between the total inhibition of adult emergence and larval mortality percentages that increased with the increase of chitin synthesis inhibitor (flufenoxuron) concentrations. Imam (2001) confirmed the present results as he stated that the effect of crude chitinase could be extended from the larval stage to pupal and adult ones because of its latent effect during these stages.

The results of probit analysis for estimation of $\mathrm{LC}_{50}$ value for G. mellonella larval mortality are presented in Fig. 5. The $\mathrm{LC}_{50}$ value of crude chitinase was $135 \mathrm{U} / \mathrm{mg}$ protein (Table 4). From the previous results, it is obvious that the crude chitinase caused considerable toxic effects to G. mellonella. The bacterium has previously exhibited

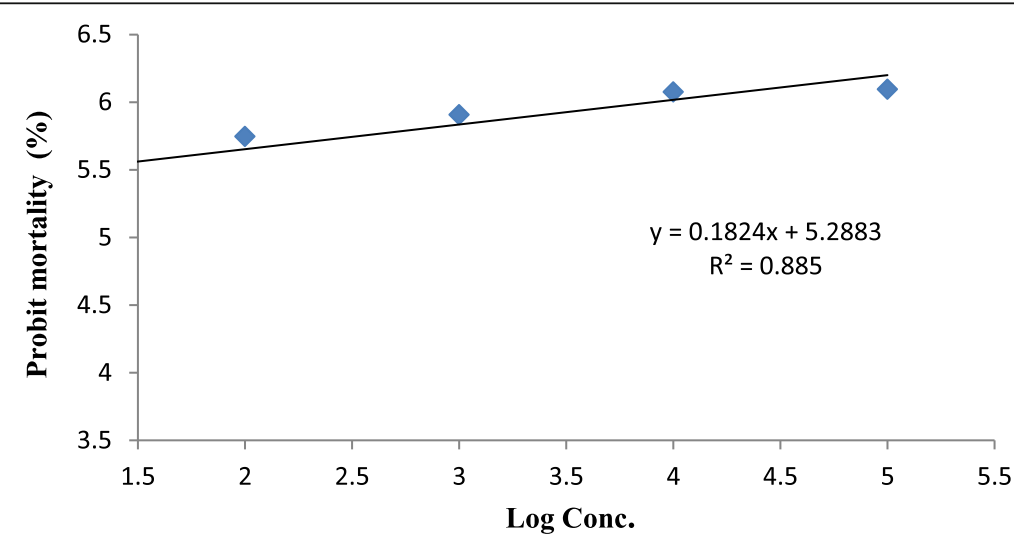

Fig. 5 Toxicity line of crude chitinase against Galleria mellonella 
Table 5 Effect of crude chitinase on fecundity and sex ratio of Galleria mellonella, treated as first larval instar

\begin{tabular}{lllll}
\hline Conc. (U/mg protein) & Sex ratio (female/total) & No. of egg/female (fecundity) \pm SE & Deficient fecundity (\%) & Oviposition deterrent index (\%) \\
\hline 0 & 0.31 & $156.6 \pm 43^{\mathrm{a}}$ & 0.00 & 0.00 \\
185 & 0.37 & $68.3 \pm 31^{\mathrm{ab}}$ & 56.38 & 39.26 \\
205 & 0.50 & $56.0 \pm 56.56^{\mathrm{ab}}$ & 64.24 & 47.31 \\
235 & 0.75 & $39.6 \pm 39.66^{\mathrm{ab}}$ & 74.71 & 59.63 \\
265 & 0.66 & $0.0 \pm 0.00^{\mathrm{b}}$ & 100.00 & 100.00 \\
295 & 1.00 & $0.0 \pm 0.0^{\mathrm{b}}$ & 100.00 & 100.00
\end{tabular}

Data are presented as the mean value \pm SE

Means in the same columns followed by the same letters are not significantly different

the potential to be an insecticidal agent against Culex quinquefasciatus Say (Diptera: Culicidae) larvae in native water (Halder et al. 2012).

\section{Effect of crude chitinase on fecundity and sex ratio of G. mellonella}

Data in Table 5 demonstrates that the sex ratio of adults emerged from treated larvae was female biased. Sex ratio increased with the increase in crude chitinase concentrations. They were $0.31,0.37,0.50,0.75,0.66$, and $1.00 \mathrm{fe}-$ male/total for concentrations of $0,185,205,235,265$, and $295 \mathrm{U} / \mathrm{mg}$ protein, respectively. This declares that males of G. mellonella were more susceptible than females to crude chitinase. This was previously reported by El-Bokl et al. (2010) as neem affected males more than females during their growth. Factors that might account for sexual differences in susceptibility include differences in body mass and immune response. Males are more susceptible to diseases, whereas females often have stronger immune responses, which may contribute to high incidence of autoimmune diseases and malignancies (Kecko et al. 2017). Although females were the dominant of emerged adults after treatment, studying the fecundity of these females showed that females were sterile at high concentrations (265 and $295 \mathrm{U} / \mathrm{mg}$ protein) (Table 5). Deficient fecundity (percentage) and oviposition deterrent index (percentage) were increased by the increase in crude chitinase concentrations. The reduction in the total number of eggs per female in this study was concentration-dependent. These results agree with that obtained by Kaur et al. (2014) as they demonstated that significant decline in adult emergence, adult longevity, fecundity, and percentages hatching of Spodoptera litura (Fab.) (Lepidoptera: Noctuidae) was recorded at higher concentrations of secondary metabolites from Streptomyces hydrogenans DH16 along with morphological abnormalities than the control. Soltani and Soltani-Mazouni (1992) attributed this to the decrease in the concentration of yolk proteins, carbohydrates, lipids, and inhibition in both DNA and RNA synthesis in the ovaries of Cydia pomonella L. (Lepidoptera, Tortricidae) females when its larvae were treated with
Diflubenzuron. Moreover, they caused vacuolation of nurse cells and oocytes of the ovaries. The same authors also mentioned that the reduction in fecundity might be attributed to the reduction in longevity and the number of oocytes per ovary and the reduction in oviposition period.

\section{Conclusion}

The present study revealed that out of 35 collected bacterial isolates, A. hydrophila showed the highest chitinolytic activity. Toxicological studies of $A$. hydrophila chitinase against G. mellonella support the chitinolytic bacterial isolate as a promising biocontrol agent against insect pests.

\section{Acknowledgements}

Not applicable.

Funding

Not applicable.

Availability of data and material

All datasets are presented in the main manuscript.

Authors' contributions

All authors contributed in, read, and approved the final manuscript.

Ethics approval and consent to participate

Not applicable.

Consent for publication

Not applicable.

Competing interests

The authors declare that they have no competing interests

\section{Publisher's Note}

Springer Nature remains neutral with regard to jurisdictional claims in published maps and institutional affiliations.

\section{Author details}

${ }^{1}$ Botany and Microbiology Department, Faculty of Science, Helwan University, Cairo, Egypt. ${ }^{2}$ Plant protection Department, Desert Research Center, Cairo, Egypt.

Received: 11 December 2018 Accepted: 15 February 2019

Published online: 22 March 2019

\section{References}

Abada EA, El-Hendawy HH, Osman ME, Hafez MA (2014) Antimicrobial activity of Bacillus circulans isolated from rhizosphere of Medicago sativa. Life Science Journal 11:711-719 
Abbott SL, Cheung WK, Janda JM (2003) The genus Aeromonas: biochemical characteristics, atypical reactions, and phenotypic identification schemes. J Clin Microbiol 41:2348-2357

Abbott WS (1925) A method of computing the effectiveness of an insecticide. J Econ Entomol 18:265-267

Aggarwal C, Paul S, Tripathi V, Paul B, Khan MA (2015) Chitinolytic activity in Serratia marcescens (strain SEN) and potency against different larval instars of Spodoptera litura with effect of sublethal doses on insect development. BioControl 60:631-640

Aggarwal C, Paul S, Tripathi V, Paul B, Khan MA (2017) Characterization of putative virulence factors of Serratia marcescens strain SEN for pathogenesis in Spodoptera litura. J Invertebr Pathol 143:115-123

Bahar AA, Sezen K, Demirbağ Z, Nalçacioğlu R (2012) The relationship between insecticidal effects and chitinase activities of Coleopteran-originated entomopathogens and their chitinolytic profile. Ann Microbiol 62:647-653

Bakr RF, El-Barky N, Abd Elaziz M, Awad M, Abd El-Halim H (2010) Effect of chitin synthesis inhibitors (flufenoxuron) on some biological and biochemical aspects of the cotton leaf worm Spodoptera littoralis Bosid.(Lepidoptera: Noctuidae). J biolog Sci 2:43-56

Bhatnagar A, Bareth SS (2004) Development of low cost, high quality diet for greater wax moth, Galleria mellonella (Linnaeus). Indian J Ent 66(3):251-255

Binod P, Sandhya C, Suma P, Szakacs G, Pandey A (2007a) Fungal biosynthesis of endochitinase and chitobiase in solid state fermentation and their application for the production of N-acetyl-D-glucosamine from colloidal chitin. Bioresour Technol 98:2742-2748

Binod P, Sukumaran R, Shirke S, Rajput J, Pandey A (2007b) Evaluation of fungal culture filtrate containing chitinase as a biocontrol agent against Helicoverpa armigera. J Appl Microbiol 103:1845-1852

Bonnay F, Cohen-Berros E, Hoffmann M, Kim SY, Boulianne GL, Hoffmann JA, Matt N, Reichhart J-M (2013) Big bang gene modulates gut immune tolerance in Drosophila. Proc Natl Acad Sci 110:2957-2962

Bradford MM (1976) A rapid and sensitive method for the quantitation of microgram quantities of protein utilizing the principle of protein-dye binding. Anal Biochem 72:248-254

Bradner J, Gillings M, Nevalainen K (1999) Qualitative assessment of hydrolytic activities in Antarctic microfungi grown at different temperatures on solid media. World J Microbiol Biotechnol 15:131-132

Chandrasekaran R, Revathi K, Nisha S, Kirubakaran SA, Sathish-Narayanan S, Senthil-Nathan S (2012) Physiological effect of chitinase purified from Bacillus subtilis against the tobacco cutworm Spodoptera litura Fab. Pestic Biochem Physiol 104:65-71

Duncan SM, Farrell RL, Thwaites JM, Held BW, Arenz BE, Jurgens JA, Blanchette RA (2006) Endoglucanase-producing fungi isolated from Cape Evans historic expedition hut on Ross Island, Antarctica. Environ Microbiol 8:1212-1219

El-Bokl MM, Baker RF, El-Gammal HL, Mahmoud MZ (2010) Biological and histopathological effects of some insecticidal agents against red palm weevil Rhynchophorus ferrugineus. Egyptian Academic Journal of Biological Sciences: Histology and Histochemistry 1:7-22

EL-Hendway HH, Osman ME, Abd EL-Salam MR (2008) Chitinase production by Serratia marcescens and its antagonism against plant pathogenic fungi. $\mathrm{N}$ Egypt J Microbial 21:1-20

Elieh-Ali-Komi D, Hamblin MR (2016) Chitin and chitosan: production and application of versatile biomedical nanomaterials. Int J Adv Res (Indore) 4:411-427

Erdem B, KARIPTAŞ E, Cil E, IŞIK K (2011) Biochemical identification and numerical taxonomy of Aeromonas spp. isolated from food samples in Turkey. Turk Biol 35:463-472

Finney DJ (1971) Probit Analysis. 3rd Edition, Cambridge University Press, London

Flach J, Pilet P-E, Jolles P (1992) What's new in chitinase research? Experientia 48: $701-716$

Ghanem KM, Al-Garni SM, Al-Makishah NH (2011) Statistical optimization of cultural conditions for chitinase production from fish scales waste by Aspergillus terreus. Afr J Biotechnol 9:5135-5146

Halder SK, Maity C, Jana A, Pati BR, Mondal KC (2012) Chitinolytic enzymes from the newly isolated Aeromonas hydrophila SBK1: study of the mosquitocidal activity. BioControl 57:441-449

Huang XP, Renwick J, Chew FS (1994) Oviposition stimulants and deterrents control acceptance of Alliaria petiolata by Pieris rapae and $P$. napi oleracea. Chemoecology 5:79-87

Imam Al (2001) Comparative biological and toxicological studies on the effect of Bacillus thuringiensis and neem formulations on Pectinophora gossypiella. M. Sc. Faculty of Scienc, Ain Shams Univ, Cairo, Egypt
Jabeen F, Hussain A, Manzoor M, Younis T, Rasul A, Qazi Jl (2018) Potential of bacterial chitinolytic, Stenotrophomonas maltophilia, in biological control of termites. Egyptian Journal of Biological Pest Control 28:86

Karthik N, Akanksha K, Binod P, Pandey A (2014) Production, purification and properties of fungal chitinases_a review. Indian J Exp Biol 52:1025-1035

Karunya SK (2011) Optimization and purification of chitinase produced by Bacillus subtilis and its antifungal activity against plant pathogens. International Journal of Pharmaceutical \& Biological Archive 2:1633-1638

Kaur T, Vasudev A, Sohal SK, Manhas RK (2014) Insecticidal and growth inhibitory potential of Streptomyces hydrogenans DH16 on major pest of India, Spodoptera litura (Fab.)(Lepidoptera: Noctuidae). BMC Microbiol 14:227

Kecko S, Mihailova A, Kangassalo K, Elferts D, Krama T, Krams R, Luoto S, Rantala MJ, Krams IA (2017) Sex-specific compensatory growth in the larvae of the greater wax moth Galleria mellonella. J Evol Biol 30:1910-1918

Khan S, Guo L, Maimaiti Y, Mijit M, Qiu D (2012) Entomopathogenic fungi as microbial biocontrol agent. Molecular Plant Breeding 3:63-79

Kitamura E, Kamei Y (2003) Molecular cloning, sequencing and expression of the gene encoding a novel chitinase $A$ from a marine bacterium, Pseudomonas sp. PE2, and its domain structure. Appl Microbiol Biotechnol 61:140-149

Kramer KJ, Koga D (1986) Insect chitin. Insect Biochemistry 16:851-877

Kuddus M, Ahmad I (2013) Isolation of novel chitinolytic bacteria and production optimization of extracellular chitinase. Journal of Genetic Engineering and Biotechnology 11:39-46

Martin-Carnahan A, Joseph SW (2005) Genus 1. Aeromans. In Bergey's manual of systematic bacteriology, 2nd edn, vol. 2, part B, p. 557-587. Edited by DJ Brenner, NR Krieg, JT Staley \& GM Garrity. New York: Springer

Merino S, Tomás JM (2016) The flgt protein is involved in Aeromonas hydrophila polar flagella stability and not affects anchorage of lateral flagella. Front Microbiol 7:1-15

Miller GL (1959) Use of dinitrosalicylic acid reagent for determination of reducing sugar. Anal Chem 31:426-428

Nawani N, Kapadnis B (2005) Optimization of chitinase production using statistics based experimental designs. Process Biochem 40:651-660

Priya C, Jagannathan N, Kalaichelvan P (2011) Production of chitinase by Streptomyces hygroscopicus VMCH2 by optimisation of cultural conditions. Int J Pharm Bio Sci 2:B210-B219

Roberts WK, Selitrennikoff CP (1988) Plant and bacterial chitinases differ in antifungal activity. Microbiology 134:169-176

Soltani N, Soltani-Mazouni N (1992) Diflubenzuron and oogenesis in the codling moth, Cydia pomonella (L.). Pestic Sci 34:257-261

Stock SP (2009) Insect pathogens: molecular approaches and techniques. CABI

Tariq R (2015) Characterization of an indigenous Serratia marcescens strain TRL isolated from fish market soil and cloning of its chiA gen. World Journal of Fish and Marine Sciences 7:424-434

Thakkar A, Patel R, Thakkar J (2016) Partial purification and optimization of chitinase form Bacillus spp. Journal of Microbiology and Biotechnology Research 6:26-33

Ulhoa CJ, Peberdy JF (1991) Regulation of chitinase synthesis in Trichoderma harzianum. Microbiology 137:2163-2169

Zarei M, Aminzadeh S, Zolgharnein H, Safahieh A, Daliri M, Noghabi KA, Ghoroghi A, Motallebi A (2011) Characterization of a chitinase with antifungal activity from a native Serratia marcescens B4A. Braz J Microbiol 42:1017-1029

Zarei M, Aminzadeh S, Zolgharnein H, Safahieh A, Ghoroghi A, Motallebi A, Daliri M, Lotfi AS (2010) Serratia marcescens B4A chitinase product optimization using Taguchi approach. Iran J Biotechnol 8:252-262 